\title{
O maximalismo como problema: circulação e apropriação da ideia de bolchevismo no movimento operário brasileiro durante os primeiros anos da Revolução Russa
}

\author{
Maximalism as a problem: circulation and appropriation of the idea of \\ Bolshevism in the labor movement during the early years of the \\ Russian Revolution
}

Frederico Duarte Bartz ${ }^{*}$

\begin{abstract}
Resumo: Neste artigo vou discutir as múltiplas formas como o bolchevismo foi compreendido e apropriado por militantes do movimento operário brasileiro durante os primeiros anos da Revolução Russa, entre 1917 e 1919. Este período de tempo é importante porque foi quando a idéia de "maximalismo" (que era a tradução Português para o termo bolchevismo), circulou de forma mais criativa entre os trabalhadores. $\mathrm{O}$ termo maximalismo não pode ser visto apenas como uma interpretação enganosa ou má tradução, porque o surgimento deste conceito promoveu um debate sobre novas concepções de revolução social entre os trabalhadores organizados.
\end{abstract}

Palavras-Chave: Movimento Operário Brasileiro, Maximalismo, Revolução Russa.

\begin{abstract}
In this article I will discuss the multiple forms as the Bolshevism was understood and appropriated by militants of the Brazilian labor movement during the early years of the Russian Revolution, between 1917 and 1919. This period of time is important because it was when the idea of "maximalism" (which was the Portuguese translation for the term Bolshevism), circulated so more creatively among the workers. The term maximalism can not be seen only as a misleading interpretation or mistranslation, because the emergence of this concept fostered a debate on new conceptions of social revolution among organized workers.
\end{abstract}

Keywords: Brazilian Workers Movement, Maximalism, Russian Revolution.

Recibido: 7 junio 2016

Aceptado: 9 septiembre 2016

\footnotetext{
* Brasileiro, doutorado em Programa de Pós-Graduação em História UFRGS pela Universidade Federal do Rio Grande do Sul, duarte_frederico@ hotmail.com
} 


\section{Introdução}

Neste artigo analisarei como se desenvolveu o debate em torno do maximalismo, termo que aparece na imprensa operária brasileira a partir do início da Revolução Russa, em 1917, tendo uma presença constante nestes mesmos meios de comunicação até os primeiros anos da década de 1920. O maximalismo seria a tradução portuguesa do termo bolchevismo; não acredito, no entanto, que a proliferação deste termo e o debate em torno dele se esgote no registro de uma tradução mal concebida. $\mathrm{O}$ surgimento do maximalismo permitiu o debate em torno de um novo tipo de Revolução Social e o desenvolvimento de interpretações particulares por parte de militantes anarquistas e sindicalistas revolucionários a partir das informações que vinham da Europa. Por esta razão, através do mapeamento dos debates em torno do maximalismo nos principais centros de mobilização do país, entre os anos de 1917 e 1919 (que foram os anos de mobilização mais intensa do movimento operário na Primeira República), analisarei como as discussões em torno deste conceito refletiram mudanças nas concepções destes militantes, o que pode ajudar a compreender a formulação dos projetos que visavam tornar vitoriosa a Revolução Social no Brasil.

\section{O maximalismo como problema}

Desde o primeiro momento em que se iniciou o processo revolucionário na Rússia, os militantes brasileiros receberam suas notícias com um incrível entusiasmo. Existia já nas organizações operárias brasileiras uma tradição de receber e transmitir correspondência internacional, assim como apoiar movimentos reivindicativos em diversas partes do mundo. Um dos pilares do movimento libertário era seu internacionalismo, desta forma, as lutas travadas pelos trabalhadores de outras nações eram encaradas como parte do movimento universal de libertação da humanidade. Isto se torna muito claro com o exemplo da Revolução Russa ${ }^{1}$.

A Revolução Russa foi um grande acontecimento, tanto pelas condições em que emergiu, como fruto de um levantamento operário que derrubaria a tirania secular dos czares Romanoff, como pelo momento que a Europa vivia, pois o continente estava no auge da Grande Guerra Mundial que havia se iniciado em 1914. Se não bastasse todas estas circunstâncias, a conjuntura vivida pelos trabalhadores brasileiros também imprimia um caráter especial à interpretação da Revolução Russa. A Guerra Mundial que havia degradado as condições de vida do proletariado europeu, também havia jogado seu papel em terras brasileiras, com o aumento constante da carestia de vida. Premido pelas duras condições econômicas, os trabalhadores brasileiros engajaram-se em um longo ciclo de mobilizações que iniciou-se em 1917 e só terminaria no início da década de 1920, momento que teve na Greve Geral de 1917 em São Paulo um dos seus momentos mais

1 A Revolução Russa, apesar de toda sua importância, não foi o único movimento internacional, nem o primeiro, a despertar o interesse dos militantes brasileiros. Para um outro exemplo, ver SOUSA, Fábio da Silva. Operários e Camponeses. A repercussão da Revolução Mexicana na Imprensa Operária Brasileira (1910 - 1920). Assis: Faculdade de Ciências e Letras da UNESP, Assis, 2010 (Dissertação de Mestrado). 
significativos $^{2}$.

Por esta razão, notícias sobre a Revolução e sobre os grupos políticos que atuavam na Rússia tornaram-se bastante comuns na imprensa operária, tendo destaque o papel dos "maximalistas". Maximalista seria uma das traduções possíveis para o português do termo "bolchevista", maioria em russo, devido a este grupo ter se constituído na fração majoritária do Congresso do Partido Operário Social Democrata Russo (POSDR) em 1903. Este grupo se tornou a ala mais radical do marxismo russo, contrapondo-se aos mencheviques, a minoria $^{3}$.

Existem poucas referências que problematizem o surgimento e a proliferação das referências ao maximalismo na imprensa operária daquele momento. Luiz Alberto Moniz Bandeira, em seu "O Ano Vermelho. A Revolução Russa e seus reflexos no Brasil”, ao indicar que o movimento operário estava "sob o signo do maximalismo", aponta para as paixões despertadas, mas também para as contradições e confusões que marcaram este momento inicial de impacto da Revolução Russa, como pode ser visto no jornal carioca $A$ Noite, que publicou uma notícia que indicava que os maximalistas eram seguidores do escritor Máximo Gorky ${ }^{4}$. Certamente foi o caráter a princípio contraditório destas apropriações, como o entusiasmo de muitos libertários pelo bolchevismo, que tornaram a questão do maximalismo como algo difícil de delimitar. Neste sentido, tais apropriações seriam parte do que Ângela de Castro Gomes chamou de um "emaranhado de posições”, de difícil definição e que talvez não tivesse muitas consequências políticas a posteriori ${ }^{5}$.

Mesmo que seja difícil caracterizar as posições políticas neste momento de entusiasmo, proponho-me, neste artigo, a estudar brevemente a circulação de notícias relacionadas ao maximalismo e suas diferentes formas de apropriação pelos militantes operários no período das grandes greves da Primeira República. Parto da noção de circulação das ideias, como elaborada pelo historiador chileno Eduardo Devés Valdes, em vez de simples difusão ou influência, porque se afastam da imagem do receptor passivo e toleram melhor questões relacionadas à recepção e reelaboração ${ }^{6}$. Para esta análise, utilizarei referências de jornais operários (o principal veículo para a circulação de ideias dentro do movimento) dos principais centros de militância do país entre os anos de 1917, quando inicia a Revolução Russa e o ano de 1919, que marca o auge das mobilizações operárias, mas que também já registra a chegada das primeiras críticas aos bolchevistas

2 Para o período que antecedeu ao ciclo de grandes greves, ver: FAUSTO, Boris. Trabalho urbano e conflito social. São Paulo: DIFEL, 1977. p.157 e BATALHA. Cláudio Henrique de Moraes. O movimento operário na Primeira República. Rio de Janeiro: Jorge Zahar, 2000. p. 48-49.

3 Sobre Revolução Russa, ver BROUÉ, Pierre. União Soviética. Da revolução ao colapso. Porto Alegre: Síntese Universitária/Editora da UFRGS. 1996. Para a caracterização dos grupos políticos da Rússia e sua história ver: REIS FILHO, Daniel Aarão. Rússia (1917-1921): anos vermelhos. São Paulo: Brasiliense, 1983. Capítulo "Revolta contra o czarismo". p. 22-36.

$4 \quad$ MONIZ BANDEIRA, Luiz Alberto. O ano vermelho. A Revolução Russa e seus reflexos no Brasil. São Paulo: Expressão Popular, 2004.

5 GOMES, Ângela de Castro. A invenção do trabalhismo. São Paulo: Vértice. 1988. pp.138-139, 150154.

6 VALDES, Eduardo Devés. El transpaso del pensamiento de América latina à África a través de los intelectuales caribeños, História UNISINOS, São Leopoldo, Vol. 4, n. 2, jul./dez. 2000. pp. 190-191. 
vindas de pensadores libertários da Europa, o que problematizaria ainda mais a apropriação destas referências, que passariam a colidir cada vez mais com os princípios libertários. No primeiro capítulo, tratarei da circulação das notícias sobre a Revolução Russa e o bolchevismo, no segundo, me aterei com mais cuidado a diferentes formas de apropriação do termo maximalismo feitas pelos militantes brasileiros.

\section{O maximalismo na ordem do dia: a circulação dos temas da Revolução Russa no movimento operário brasileiro}

A Rússia e sua grande revolução tornaram-se um espelho das aspirações operárias, por esta razão as informações que chegavam ao Brasil pelas agências de notícias circulavam intensamente pelos órgãos de imprensa do movimento. Este interesse ficou demonstrado muito cedo e pode ser encontrado em publicações de diversas partes do país. Assim, no primeiro número do A Semana Social, jornal editado na cidade de Maceió pelo gráfico Antônio Bernardo Canellas, no dia 30 de março de 1917 (ou seja, logo após a Revolução de Fevereiro), já aparece um artigo intitulado "A Revolução Russa: a suas causas e possíveis consequências", em que o autor do texto afirma que o acontecimento só poderia ser analisado sob a "lente do materialismo histórico", explicando que o levantamento tinha suas raízes na Guerra Mundial e na política expansionista da Alemanha; apesar disto, os social-democratas na Alemanha e seus companheiros em outros países seriam atingidos pelo gérmen da revolta e acabariam com a carnificina ${ }^{7}$.

Outro espaço importante para a divulgação destas notícias era o jornal A Plebe, principal periódico anarquista de São Paulo. No seu primeiro número, saído em 9 de junho de 1917 informava-se sobre o momento emancipador que se vivia na Rússia, em um artigo intitulado "Rumo à Revolução Social", . Em seu quarto número, o mesmo jornal contava um pouco da história da Revolução Russa em uma seção intitulada "Arrebol da liberdade: a grandiosa epopeia russa”, saído à 30 de junho de $1917^{9}$. Neste texto, o articulista explicava a formação dos Soviets a partir da mobilização de trabalhadores e soldados, organizados por juntas do Partido Social Democrata, e que os novos organismos tinham todo o apoio do povo. Neste artigo, se manifesta a esperança de que esta revolução ajudasse a unir todos os revolucionários sociais do mundo. Neste mesmo momento na cidade do Rio de Janeiro, $O$ Debate, periódico no qual escrevia o líder anarquista Astrogildo Pereira, publicava em 26 de julho de 1917, "O exemplo da Rússia: graves revelações de um soldado", relatando a conversa que um jornalista teria ouvido de um militar, falando que alguns companheiros haviam se negado a atirar no povo durante a greve paulista e que inclusive teriam ajudado a arrancar os trilhos dos trens; obviamente, o artigo acaba se perguntando se teríamos no Brasil um comitê de operários e soldados ${ }^{10}$.

Como pode se perceber por estes poucos exemplos, os temas que chamavam atenção neste primeiro momento estavam ligados especialmente à continuação da Guerra e

7 A Semana Social. Maceió. p.1. 30, mar, 1917.

8 A Plebe. São Paulo. p.1, 9, jun, 1917.

9 A Plebe. São Paulo. p.2, 30, jun, 1917.

10 O Debate. Rio de Janeiro. p.7. 26, jul, 1917. 
aos atores sociais que estavam mobilizados naquela Revolução, os operários e os soldados (além do fato de seu exemplo poder servir de inspiração para os brasileiros). Além disso, porém, também se destacava o interesse pelas forças políticas que estavam atuando no âmbito revolucionário. Por mais que o cenário fosse confuso, a ponto do A Semana Social chamar o processo russo de saco de gatos ${ }^{11}$ em um artigo do dia 26 de junho, muito cedo os bolchevistas ou maximalistas chamaram atenção em meio a outros grupos. No número 4 do A Plebe, saído à 30 de junho, no já citado artigo "O arrebol da liberdade: a grandiosa epopeia russa”, aparece explicado de forma detalhada que os responsáveis pela organização dos Soviets teriam sido as juntas do Partido Social Democrata, que não haviam apoiado a guerra

Por isso, logo que romperam os tumultos em Petrogrado - tumultos, a princípio, de caráter puramente economico - os socialistas russos, amparados pela confiança da classe operaria, tomaram a direção do movimento revolucionário, que está longe de ter acabado. A Junta Central do Partido Social Democrático lançou um manifesto convidando os operários e os soldados a nomearem delegados a um Conselho, destinado a lutar contra as forças da reação e a fiscalizar os atos do Governo Provisório. Este Conselho, que tomou o lugar da Duma no Palácio Tauride, tem ininterruptamente exercido uma acção inovadora e revolucionária ${ }^{12}$.

Isto é bastante surpreendente, principalmente quando contraposto à tese de que havia uma crença geral de que a Revolução Russa era obra de anarquistas. Tanto esta crença não se sustenta (pelo menos não de forma generalizada), que no dia 28 de julho, $A$ Plebe no artigo "Algo sobre a Revolução Russa", lamentava-se a inexistência de um movimento anarquista forte no país dos Czares, valendo-se de opiniões de Deputados socialistas, publicados em jornais europeus, para traçar um perfil da Revolução ${ }^{13}$. No dia 18 de agosto, na página 2 do A Plebe, a seção "Arrebol da liberdade: ao redor da epopéia russa”, traça um rápido perfil de Lênin como líder dos socialistas e de seu apelo contra a continuação da Guerra Mundial $^{14}$.

$\mathrm{O}$ interesse pelo maximalismo ou pelo bolchevismo, no entanto, vai tomar um impulso muito maior a partir de novembro de 1917, quando este grupo político tomar o poder na Rússia, derrubando o Governo Provisório e proclamando o Soviet de Operários e Soldados como órgão máximo da República Russa. Antes de novembro de 1917, os órgãos de imprensa do movimento operário noticiavam e debatiam uma revolução com nítido caráter popular, mas cujos grupos que representavam estas forças populares ainda não havia tomado o poder. Deste modo, o que mais vai causar impacto neste momento inicial são algumas formas novas de ação, como a formação do Soviet e a participação ativa dos soldados, que podiam ser consideradas novas práticas, incomuns para a tradição de luta do movimento operário brasileiro. Com a Revolução de Outubro, o cenário muda: novas

11 A Semana Social. Maceió. p.3. 26, jun, 1917.

12 A Plebe. São Paulo. p.2, 30, jun, 1917.

13 A Plebe. São Paulo. p.2-3, 28, jul, 1917.

14 A Plebe. São Paulo. p.2, 18, ago, 1917. 
questões vão ser colocadas e o significado do maximalismo será uma delas.

Um dos órgãos de impensa que testemunham este interesse é $O$ Cosmopolita, jornal do Centro Cosmopolita do Rio de Janeiro, sindicato dos empregados em hotéis da Capital Federal. No dia $1^{\circ}$ de dezembro este jornal publica o artigo "Os Massimalistas", de autoria de A.G. (provavelmente Antônio Gramsci), traduzido do periódico socialista $\mathrm{Il}$ Grido del Popolo, de Turim, pelo jornal português Aurora. Neste texto os maximalistas são mostrados como a própria Revolução Russa, pois eles levaram adiante a ideia revolucionária, não pararam no tempo, não se institucionalizaram e não estavam ligados ao passado; eles são mostrados como socialistas que não compactuavam com o evolucionismo: "encarnam a ideia limite do socialismo: são "todo o socialismo". Além disso, no texto afirma-se que eles eram alimentados pelo marxismo ${ }^{15}$.

Por mais que este texto reflita problemas internos do Partido Socialista Italiano, é interessante observar sua chegada e circulação no Brasil, o que é uma prova de que os militantes podiam ter acesso a materiais que estavam sendo produzidos na Europa e a debates que estavam sendo desenvolvidos dentro do movimento operário europeu de uma forma bastante rápida. Também começa a haver um interesse pelos personagens da Revolução. No dia 15 de dezembro, o jornal $O$ Cosmopolita trazia uma biografia de Trotsky em "Sobre a Revolução Russa" "16 e no dia 15 de janeiro de 1918, aparece o texto “Estrangeiro na própria pátria”, com uma biografia de Lenin, em que o líder bolchevista é apontado como o líder da social democracia russa e um fervoroso defensor das ideias de Karl Marx ${ }^{17}$.

Este desejo de informar e esclarecer não se justificava apenas pelos caminhos abertos pela Revolução Russa, como exemplo para o movimento operário do resto do mundo, mas também porque as notícias que difamavam a Rússia e os maximalistas eram um argumento para as forças conservadores que atacavam a ação dos militantes a partir dos jornais de grande circulação. Desta forma, se justificavam as palavras do articulista do jornal A Luta, de Porto Alegre, de 28 de março de 1918, na seção "Rússia", quando afirmava peremptoriamente que "nós que estudamos as questões sociais, não podemos e não devemos calar; precisamos esclarecer a imprensa fraldiqueira, desmentindo as suas calúnias, esclarecendo os trabalhadores e fazendo justiça aos maximalistas" ${ }^{18}$. Nesta mesma linha segue a Tribuna do Povo, de Recife, quando no dia $1^{\circ}$ de junho de 1918 publica o artigo "Esclarecendo", em que procurava rebater as acusações que fez o Diário de Pernambuco, contra o presumido financiamento alemão à Revolução de Trotsky e Lenin $^{19}$. No dia 10 de julho, aparecia o artigo "Os maximalistas e os jornais burgueses" que continuava a rebater a crítica que a grande imprensa fazia à suposta "traição russa", acusação feita contra os bolchevistas por terem abandonado a Guerra e firmado o Tratado de Brest Litovisky com a Alemanha. Criticando esta interpretação, o periódico mostrava que não havia nenhum sentido nesta acusação, pois a Rússia Revolucionária derrubaria a

15 O Cosmopolita. Rio de Janeiro. p.1. $1^{\circ} \mathrm{dez}, 1917$.

16 O Cosmopolita. Rio de Janeiro. p.1-2. 15, dez, 1917.

17 O Cosmopolita. Rio de Janeiro. p.1. 15, jan, 1918.

18 A Luta, Porto Alegre, p.2, 28, mar, 1918.

19 Tribuna do Povo. Recife, p.1. 1º jun, 1918. 
Alemanha e o restante da Europa capitalista ${ }^{20}$.

Depois de novembro de 1918, quando estoura a Revolução Alemã, sopra uma nova lufada de esperança nos militantes, pois seria o caminho para o fim da Guerra e a expansão do maximalismo para o restante da Europa. No dia 20 de novembro, a mesma Tribuna do Povo estampava na primeira página sob o título de "No limiar da nova era", um texto que iniciava com estas comoventes palavras:

Felizes os homens de hoje, pois seus olhos se vão recrear no mais imponente espetáculo da história: o triunfo da liberdade sobre a tirania. A vitória das ideias socialista-anarquistas, que representam a causa da Liberdade, é coisa de que em boa fé já não se pode mais duvidar. Esta guerra, que representava as mais altas esperanças da burguesia está dando resultado inteiramente diferente do que convinha aos interesses dos que a desencadearam. Supunham os burgueses que desta luta colossal entre os principais países do orbe o seu poder saísse prestigiado e consolidadas ficassem suas sagradas instituições. Mas a guerra suscitou tantas e tão variadas questões; pôs em jogo tão variados interesses e criou uma situação tal, que a organização burguesa terá de abrir falência. E à falência da organização burguesa sucederá o estabelecimento de uma sociedade socialista, que se iniciará com o mesmo programa do maximalismo russo.

A partir deste ponto, explicava o avanço e vitória das forças "socialistasanarquistas" em âmbito mundial: "Agora, admitida como está a implantação do bolshevikismo em todos os países, inclusive o Brasil, é necessário esclarecer o que ele é”. O bolshevikismo ou o maximalismo seriam, conforme o jornal, a concepção máxima da teoria socialista ${ }^{21}$. Um exemplo disso, ainda na Tribuna do Povo, é o artigo "A ditadura proletária”, em que se procura diferenciar o socialismo burguês, que tratava apenas de manter a democracia e o capitalismo, da ditadura proletária, alcançada a partir do maximalismo: "Para maior esclarecimento da questão, apresentamos aqui a definição exata do maximalismo. O MAXIMALISMO É A APLICAÇÃO DO MÁXIMO DAS CONCEPÇÕES SOCIALÍSTICAS, POR MEIO DA DITADURA PROLETÁRIA "22.

Durante o ano de 1919, continuaram a circular notícias sobre o maximalismo e sobre o bolchevismo, tentando explicar o comunismo russo e como grupos políticos similares passavam a agir no restante da Europa, em países como a Hungria e a Alemanha. Mais importante ainda é que documentos vindos dos países europeus começaram a chegar com mais intensidade, acrescentando novas cores ao debate. Alguns exemplos desta circulação de informações em diferentes centros podem ser vistos na Tribuna do Povo, do dia $1^{\circ}$ de janeiro de 1919, em que foram publicados os sete pontos do "Pacto Fundamental da República dos Soviets" ${ }^{\text {,23 }}$; em O Syndicalista de Porto Alegre, aparece no dia $1^{\circ}$ de maio a "Mensagem de Máximo Gorky aos trabalhadores do mundo",24; no A Plebe, de São Paulo, do dia 5 de junho surge um documento intitulado "A República Socialista Federal

Tribuna do Povo. Recife, p.2-3. 10, jul, 1918.

Tribuna do Povo. Recife, p.1. 20, nov, 1918.

22 Tribuna do Povo. Recife, p.1. 20, dez, 1918.
23 Tribuna do Povo. Recife, p.1. $1^{\mathbf{o}}$, jan, 1919.

24 O Syndicalista. Porto Alegre, p.4, 1º de maio, 1919. 
dos Soviets. Aos soldados de todo mundo" 25 ; no Spartacus do Rio de Janeiro, foi publicado o Manifesto de fundação da III Internacional, no dia 8 de novembro.

Esta circulação demandava esclarecimento por parte da militância e foi neste ano de 1919 em que ocorrre uma das tentativas mais sistemáticas de fazer isso em relação ao maximalismo. Como tentativa de explanação das ideias que eram consideradas bolchevistas, os militantes Antônio Candeias Duarte e Edgar Leuenroth, que atuavam em São Paulo, escreveram "O que é maximismo ou bolchevismo - o programa comunista”. Este era um esboço constitucional inspirado em alguns pontos estabelecidos pelo III Congresso dos Soviets de janeiro de 1918 para uma república comunal, organizada em conselhos e gerida pelos trabalhadores. Nos termos de Moniz Bandeira, em seu livro " $O$ Ano Vermelho": "Era todo um princípio de organização, em que se entrelaçavam ideias libertárias e inovações da ditadura do proletariado na Rússia”26.

Com a chegada de mais referências vindas da Europa, também começam a aparecer as primeiras críticas e sinais de que não havia total concordância entre libertários e bolchevistas em termos de métodos e objetivos. No dia 11 de outubro de 1919, é publicado no Spartacus do Rio de Janeiro "O bolshevismo ante a atitude anarquista", do francês Sebastien Faure, em que o autor afirma não saber ao certo qual atitude tomar diante dos bolchevistas, dizendo entender o momento da Guerra, mas, se a ditadura se perpetuasse, seria contrario a ela ${ }^{27}$. No dia 6 de dezembro, é publicada uma "Carta de Koprotkin", redigida pelo famoso libertário russo, em que este se opõe a ditadura de uma "fração do Partido Social Democrático", comparando-o ao jacobinismo ${ }^{28}$. Surgem também as primeiras críticas de militantes locais, que, se não eram explicitas, ao menos apontavam para referências ligadas ao maximalismo. Isto pode ser visto em um texto do militante Friedrich Kniestedt chamado "O que nós comunistas queremos", publicado em $O$ Syndicalista de Porto Alegre em 3 de setembro, em que este defende a formação de uma sociedade a partir de grupos operários organizados em um comunismo claramente libertário, por oposição a algo que não era deixado totalmente claro: "Pretendendo pois a todas as aspirações comunistas de outrora, a constituição de um complicado estado econômico, é preciso, até na denominação que adotamos, constatar nossa opinião divergente e por isso nos denominar comunistas-anarquistas

Todas estas críticas se multiplicariam a partir do ano seguinte, quando o movimento operário passa a sofrer um refluxo pelo aumento da repressão e tornam-se mais comuns as notícias do antagonismo dos bolchevistas aos libertários russos. Se iniciaria, a partir daí, o processo que dividiria os militantes comunistas daqueles de orientação libertária. $\mathrm{O}$ maximalismo deixaria cada vez mais de aparecer com este nome e suas definições tornaram-se mais precisas, principalmente com a circulação de documentos da Internacional Comunista. De qualquer forma, durante este período inicial de circulação das referências ao maximalismo e ao bolchevismo entre os militantes brasileiros, existia ainda a

25 A Plebe. São Paulo, p.2. 5, jul, 1919.

26 MONIZ BANDEIRA, Luiz Alberto. O ano vermelho. A Revolução Russa e seus reflexos no Brasil. São Paulo: Expressão Popular, 2004. pp. 229-230.

27 Spartacus. Rio de Janeiro, p.1. 11, out, 1919.

28 Spartacus. Rio de Janeiro, p.1. 6, dez, 1919.

29 O Syndicalista. Porto Alegre, p.2, 3, set, 1919. 
possibilidade de identificação, apropriação e reinterpretação destes termos, de uma forma muito mais livre do que seria possível posteriormente. Tendo visto que o maximalismo havia surgido no horizonte como grande referência revolucionária, é necessário compreender também o que era ser maximalista neste momento, ou seja, como eram feitas as apropriações deste termo pelos militantes.

O maximalismo reapropriado: o bolchevismo como reelaboração de ideias e fator de identificação entre os militantes operários brasileiros

Como foi possível ver no capítulo anterior, notícias que davam conta do que ocorria na Rússia, documentos e explicações sobre o maximalismo circularam abundantemente entre os anos de 1917 e 1919 nos principais centros de militância do país. Porém, como havia colocado no primeiro capítulo deste artigo, a circulação das ideias não é um fenômeno que caracteriza-se somente pela propagação de algumas informações, pelo contrário, por mais que houvesse a reprodução de notícias e documentos, também havia um espaço bastante grande para a reelaboração destas ideias, dependendo do lugar em que elas eram veiculadas. Neste espaço de reelaboração de uma ideia, também se dá a possibilidade de sua apropriação de diversas formas, fazendo com que o bolchevismo russo se tornasse uma gama de diversos "maximalismos" locais.

Apesar de circularem notícias bastante fidedignas sobre a orientação teórica de Lênin e da posição dos bolchevistas como ala esquerda da social-democracia russa, estas informações compartilhavam espaço com outras, que identificavam a Revolução Social no país dos czares como produto da tradição anarquista ou até de ambas correntes revolucionárias. Durante o ano de 1917, a circulação de uma grande variedade de notícias, associada às muitas referências vindas da literatura engajada, podem explicar textos como "Abaixo a farsa politica: o que o povo deve seguir", publicado na Semana Social, em 27 de outubro, em que o autor afirma que "o socialismo anarquista, ou ao menos, a social democracia, deverá substituir a farsa política que hoje se representa”, enquanto faz referências simultâneas à Karl Marx, Bakunin, Malatesta e Tolstói ${ }^{30}$. No momento em que isso era escrito em Maceió, A Plebe em São Paulo, publicava a pequena biografia de Lênin, a que já fiz referência anteriormente, mostrando-o como um dos principais líderes da Revolução e o militante João Baptista Noll, em um comício na cidade de Porto Alegre, em $1^{\circ}$ de agosto, afirmava em seu discurso que "O povo da Rússia, dos cossacos, de Tolstoi, Gorki e Kropotkine, depois de uma escravidão quase infinita, conseguiu por si um regime de liberdade,"31.

De qualquer forma, a tendência geral entre os periódicos operários é considerar o maximalismo seria a fração mais radical do socialismo. Em alguns casos isto permitia um identificação muito forte por parte dos militantes libertários, pois se relacionava

30 A Semana Social. Maceió. p.1. 27, out, 1917.

31 Esta declaração foi dada em um dos maiores comício da greve de 1917, que reuniu mais de cinco mil pessoas na Praça Senador Florêncio, atual Praça da Afândega, em Porto Alegre. BODEA, Miguel. A greve geral de 1917 e as origens do trabalhismo gaúcho: ensaio sobre o pré-ensaio de poder de uma elite política dissidente a nível nacional. Porto Alegre: L\&PM, 1979. p.36. 
diretamente à rivalidade que estes tinham com os socialistas e social-democratas, considerados moderados e colaboradores da burguesia. Na edição de $1^{\circ}$ de maio de 1918 do A Luta, de Porto Alegre, aparece um artigo intitulado "O socialismo russo e o socialismo alemão", em que se critica violentamente a social-democracia, identificada como um socialismo "burguês e politiqueiro", que procurava apoiar-se no governo e traía a classe operária. A identificação aqui dirige-se aos militantes que controlavam naquela ocasião a Federação Operária local e que se contrapunham aos anarquistas. Entende-se, então, a posição do articulista quando propõe a seguinte relação: "Socialismo alemão, social democracia, socialismo político e de estado: -socialismo burguês. Socialismo russo: maximalismo, anarquismo, sindicalismo: -socialismo operário"32. Este trecho é fundamental para compreender o que estava acontecendo, porque não só permite observar a auto-identificação com um grupo político cuja notoriedade era muito recente, mas também uma classificação de seus adversários.

Da mesma forma que esta identificação podia ser feita contra determinado grupo político, também podia se realizar uma relação complementar a outras correntes, também consideradas radicais. No dia 29 de novembro de 1919, aparece no Spartacus o artigo "Definições: bolchevismo, anarquismo, sindicalismo", um artigo que tentava explicar as diferenças entre estes grupos como uma divisão de trabalho na Revolução Social: o anarquismo alimentaria a ideia, o que se adequaria à educação da classe operária; o sindicalismo seria um tipo de organização econômica e o bolchevismo uma forma de ação para alcançar o poder:

O anarquismo é a base, uma função doutrinária, educadora e filosófica, atuando nos espíritos e nas consciências, quase como foros de religião. É um evangelho, um sacerdócio, e não tem nada com a organização sindical, nem com os interesses econômicos das classes. O sindicalismo é a organização prática, é o regime econômico e administrativo das coisas na sociedade comunista.

Bolchevismo, maximalismo, espartacismo, significam ação, preparação, organização revolucionária para a destruição violenta da sociedade burguesa e instituição de um poder proletariano, - a ditadura operária. Sovietismo é a organização econômica desta fase transitória do governo dos proletários.

O fim do anarquismo é educar, é formar mentalidades sãs, caracteres nobres e elevados que hão de amanhã constituir a sociedade nova. O fim do sindicalismo é organizar o trabalho, os sindicatos, as profissões fora da ação patronal, é garantir a produção para que nada falta na sociedade comunista-anarquista. $O$ fim do bolchevismo e do sovietismo é arrancar o poder à burguesia, é destruir as raízes da grande árvore secular; é desbravar o caminho ao sindicalismo e à anarquia; é, em resumo, fazer precipitar a revolução social. O sindicalismo é o trabalho, o labôr, a riqueza material: é o pão. $\mathrm{O}$ anarquismo é a evangelização do bem, do amor e da virtude: é a paz. Bolchevismo, maximalismo significam ação revolucionária para a conquista daqueles alvos. Bolchevismo é a guerra - ai de nós inevitável - para se chegar à paz. Porque, de duas uma: ou evolução de colaboração com a burguesia, ou revolução armada do povo contra a burguesia ${ }^{33}$.

$32 \quad$ A Luta, Porto Alegre, p.2, $1^{\circ}$, mai, 1918.

33 Spartacus. Rio de Janeiro, p.1. 29, nov, 1919. 
No fundo, estes seriam rótulos para um mesmo tipo de ação, o que é surpreendente, pois acabava com os conflitos no campo das ideias para pensar um mesmo tipo "híbrido" da forma de ação política no mundo operário.

Estas reapropriações eram possíveis pelo momento mesmo em que os militantes viviam, onde o "ser comunista" não era algo bem definido, permitindo que anarquistas e sindicalistas revolucionários aderissem à proposta sem necessariamente ter de abandonar sua orientação. Esta possibilidade se encontrava justificada por interpretações como " $O$ Significado histórico do maximalismo”, texto publicado na edição de 26 de abril de 1919 , no A Plebe, a partir de uma conferência do filósofo argentino Jose Ingenieros, em que este tentava explicar a forma de difusão da nova doutrina ao redor do mundo: "Não haverá um maximalismo uniforme e universal, mas tantos quantos são os núcleos sociológicos que recebem o benéfico influxo da presente revolução social "34. Com isto, não quero dizer que este fosse um fenômeno comum a todos os militantes, havendo aqueles (principalmente os militantes libertários mais experientes), que tinham consciência do limite desta adesão ao maximalismo. Isto mostra, porém, que a possibilidade de uma fusão entre as correntes do movimento operário aparecia como uma possibilidade naquele momento.

De qualquer modo, esta adesão abriu caminho para a constituição de grupos maximalistas ou que definiam-se por algum tipo de identificação com esta proposta. Um dos primeiros exemplos deste fenômeno pode ser observado nas eleições sindicais do Centro Cosmopolita do Rio de Janeiro. No dia 20 de julho, no artigo "Os massimalistas", publicado no "O Cosmopolita", um membro do grupo vencedor das eleições definiu sua chapa como "massimalista" e não porque os trabalhadores em hotéis fariam uma revolução, mas porque queriam o máximo de conquistas sociais e desejavam fazer uma obra renovadora:

Não se trata de começar uma Revolução Russa fomentada por trabalhadores em hotéis. O nosso intuito foi de definir dois grupos que disputam a vitória eleitoral. E como nós temos a certeza que trabalhamos pelo máximo das conquistas da classe, apropriamonos da espressão "massimalista", que sustentaremos apesar da grita dos vencidos, que tanto interesse tem demonstrado em comprometer-nos com as autoridades.

Somos "massimalistas" porque queremos sustentar o que está feito e fazer obra renovadora ${ }^{35}$.

Um outro exemplo de identificação de um grupo de militantes operários com a Revolução Russa deu-se na cidade de Porto Alegre, em novembro de 1918, a partir da ação do militante Abílio de Nequete, que era um imigrante libanês que havia tido uma forte atuação entre os operários da capital gaúcha, participando da Liga de Defesa Popular na grande greve de 1917. Após este episódio ele continuou ativo, atuando junto com os militantes libertários na União Operária Internacional, escrevendo alguns artigos em seu jornal, A Luta. Em novembro de 1918, Nequete e outros militantes resolvem fundar a União Maximalista de Porto Alegre, lançando o manifesto "Do canhão à peste: até que os

34 A Plebe. São Paulo, p.4. 26, abr, 1919.

35 O Cosmopolita. Rio de Janeiro. p.2. 20, jul, 1918. 
operários tenham consciência de sí próprios”. O manifesto não trazia nenhuma novidade em termos de orientação política, mas direcionava suas críticas para as péssimas condições de vida do operariado e para aqueles militantes que traíam sua classe empenhando seu apoio à burguesia ${ }^{36}$.

A União Maximalista continuou lançando manifestos durante o ano de 1919, além disso seu líder teve forte atuação nas greves daquele ano. De qualquer forma, as circunstâncias específicas que envolviam a fundação da União Maximalista se tornam mais claras a partir de uma carta enviada à Internacional Comunista por Abílio de Nequete alguns anos depois:

Em Porto Alegre, capital do estado do Rio Grande do Sul, em novembro de 1918, um grupo de três companheiros tomou a si o encargo de lançar um manifesto aos trabalhadores, dando causa da pandemia, então chamada espanhola, a organização ultra criminosa do capitalismo, e incitava a massa a que se apoderassem de tudo, porque tudo era criado ao seu esforço. Este manifesto levava em seu cabeço o seguinte:

MANIFESTO DA UNIÃO MAXIMALISTA AOS TRABALHADORES. E desde então o referido grupo considerou-se uma entidade revolucionária que, embora falhas em conhecimentos teóricos, apoiava em todos os momentos os feitos da gloriosa revolução russa. Uma das causas principais do grupo usar o nome UNIÃO MAXIMALISTA, foi a hostilidade que já começavam a desenvolver os anarquistas da UNIÃO OPERÁRIA INTERNACIONAL, a qual pertenciam os três membros fundadores da UNIÃO MAXIMALISTA.37

Mesmo que seja necessário matizar esta hostilidade dos libertários da União Operária Internacional em relação à Revolução Russa, é interessante ver como o maximalismo tornava-se uma referência de radicalidade para a qual os militantes podiam voltar-se quando da formação de uma nova associação operária. Neste sentido, assim como na eleição do Centro Cosmopolita, observa-se que dizer-se maximalista traduzia-se em uma adesão à uma luta mais resoluta e radical, que no caso da União Maximalista definia-se através do apoio explícito à causa revolucionária representada pela Revolução Russa.

É bom lembrar que o termo "maximalista" e "bolchevista" conviveu, neste mesmo período, com o termo comunista, tendo este um significado mais ambíguo e mais polissêmico, já que era também reivindicado pelos libertários (anarco-comunismo). De qualquer forma, na fundação de um primeiro Partido Comunista do Brasil, efetuada por militantes libertários do Rio de Janeiro, referências que apontam para o maximalismo propriamente dito aparecem ao lado das influências libertárias. Este partido, cujo programa apareceu (entre outros lugares) em $O$ Syndicalista de Porto Alegre, do dia 17 de junho de 1919, afirmava que:

36 Sobre este militante e a formação da União Maximalista, ver BARTZ, Frederico Duarte. Abílio de Nequete (1888-1960): os múltiplos caminhos de uma militância operária, História Social, Campinas, no 14/15, 2008. p.157-173.

37 Carta de Abílio de Nequete ao Comitê Executivo da Internacional Comunista. Montevidéu, $1^{\circ}$ de fevereiro de 1921. Esta carta encontra-se no RGASPI - Rossiiskii Gosudarstvennii Arkhiv Sotsialnoi i Politicheskoi Issledovanii (Arquivo do Estado Russo de História Social e Política). 
A ação do Partido consiste na propaganda sistemática, por todo o país, do socialismo integral ou comunismo e na arregimentação e educação do proletariado em geral para a conquista dos poderes públicos- único meio pelo qual poderá realizar seu programa (...).

Fiel aos princípios da Internacional, o Partido Comunista do Brasil manterá relações com todos os seus afins do exterior, com os quais será solidário ${ }^{38}$.

Mesmo que aqui não tenha sido utilizada a palavra maximalismo, percebe-se uma influência do bolchevismo russo, ao menos na ideia de filiar-se à Internacional Comunista e à conquista dos poderes públicos, reivindicação bastante distanciada da tradição libertária no Brasil, que se centrava no combate ao poder do Estado. Tanto esta afirmação contido neste programa partidário, quanto às apropriações anteriores do maximalismo, apontam para algo comum: a Revolução Russa surgia como referência de radicalidade, para onde os militantes podiam se voltar neste período das grandes mobilizações. Se este exemplo, consubstanciado no termo "maximalismo", não provocou uma profunda mudança ideológica entre os militantes, forneceu uma série de elementos que se combinaram com o arcabouço anarquista e sindicalista que orientava a ação dos militantes naquele momento. Neste caso, o maximalismo poderia aparecer como elemento político, como norteador da ação revolucionária ou como orientação para a conquista dos poderes públicos, questões que marcaram de forma profunda aquele período de grande agitação social.

\section{Conclusão}

Meu objetivo, neste artigo, não foi tirar conclusões definitivas sobre a emergência do termo maximalismo, nem as formas como este foi apropriado pelo movimento operário brasileiro durante o período das grandes mobilizações operárias da Primeira República. O que desejei aqui foi mostrar como circularam uma série de referências que interferiram nas concepções dos militantes, principalmente em relação ao que eles acreditavam ser o caminho da Revolução Social. Desta forma, inspirar-se no maximalismo não significou apenas a adesão a um modismo ou um equívoco dos libertários, mas significava ter como horizonte a radicalidade do exemplo da Revolução Russa, em um momento que o movimento operário brasileiro também vivia um momento de radicalização.

\section{Fontes}

Jornais:

A Semana Social. Maceió. 1917.

A Plebe. São Paulo. 1917,1919.

O Debate. Rio de Janeiro. 1917.

O Cosmopolita. Rio de Janeiro. 1917-1918.

38 O Syndicalista. Porto Alegre. p.1. 17, jun, 1919. 
A Luta, Porto Alegre. 1918.

A Tribuna do Povo. Recife. 1918-1919.

Spartacus. Rio de Janeiro. 1919.

Outras Fontes:

Carta de Abílio de Nequete ao Comitê Executivo da Internacional Comunista. Montevidéu, $1^{\circ}$ de fevereiro de 1921.

Bibliografia:

BARTZ, Frederico Duarte. Abílio de Nequete (1888-1960): os múltiplos caminhos de uma militância operária, História Social, Campinas, no 14/15, 2008.

BATALHA. Cláudio Henrique de Moraes. O movimento operário na Primeira República. Rio de Janeiro: Jorge Zahar, 2000.

BODEA, Miguel. A greve geral de 1917 e as origens do trabalhismo gaúcho: ensaio sobre o pré-ensaio de poder de uma elite política dissidente a nível nacional. Porto Alegre: L\&PM, 1979.

BROUÉ, Pierre. União Soviética. Da revolução ao colapso. Porto Alegre: Síntese Universitária/Editora da UFRGS. 1996.

FAUSTO, Boris. Trabalho urbano e conflito social. São Paulo: DIFEL, 1977.

GOMES, Ângela de Castro. A invenção do trabalhismo. São Paulo: Vértice. 1988.

MONIZ BANDEIRA, Luiz Alberto. O ano vermelho. A Revolução Russa e seus reflexos no Brasil. São Paulo: Expressão Popular, 2004.

REIS FILHO, Daniel Aarão. Rússia (1917-1921): anos vermelhos. São Paulo: Brasiliense, 1983.

SOUSA, Fábio da Silva. Operários e Camponeses. A repercussão da Revolução Mexicana na Imprensa Operária Brasileira (1910 - 1920). Assis: Faculdade de Ciências e Letras da UNESP, Assis, 2010 (Dissertação de mestrado).

VALDES, Eduardo Devés. El transpaso del pensamiento de América latina à África a través de los intelectuales caribeños, História UNISINOS, São Leopoldo, Vol. 4, n. 2, jul./dez. 2000. 